\title{
QUALITY OF LIFE OF IN PATIENTS SUBMITTED TO ANTERIOR ABDOMINAL WALL LAPAROSCOPIC HERNIOPLASTY
}

\author{
Qualidade de vida de pacientes submetidos à hernioplastias laparoscópicas da parede abdominal anterior
}

Ricardo Zugaib ABDALLA, Rodrigo Biscuola GARCIA, Danniel Frade SAID, Beatrice Martinez Zugaib ABDALLA

From Hospital Sírio-Libanês, São Paulo, SP Brazil.

HEADINGS - Ventral hernia. Questionnaire. Quality of life. Laparoscopic. Abdominal wall.
ABSTRACT - Background - The laparoscopic ventral hernia repair technique made possible surgeries with smaller skin incisions and smaller dissection of the soft tissue around the hernia, therefore with a better wound, a quicker postoperative recovery and a lower complication rate. Aim - To evaluate the applicability of a quality of life survey based on the molds of the American Hernia Society, European Hernia Society and Carolinas Equation for Quality of Life, through telephone in patients submitted to laparoscopic hernioplasty by IPOM technique. Methods - A retrospective cohort study was made to evaluate the quality of life of 21 patients that underwent anterior abdominal wall laparoscopic hernioplasty by intraperitoneal onlay mesh technique. Questionnaire was applied through telephone. Results - Of the 21 patients, $19 \%$ felt that the hernia recurred. Also $19 \%$ passed through another abdominal wall surgery, and among these, $75 \%$ was related to the previously hernia correction. Finally, $81 \%$ of patients did not undergo any other abdominal wall surgery. Conclusion - It was possible to apply the quality of life questionnary by telephone on patients who underwent an anterior abdominal wall. The results, in its turn, were satisfactory and showed that patients, in general, were satisfied with the surgical procedure.

\section{Correspondence: \\ Danniel Frade Said \\ Email: dfrade1990@gmail.com}

Financial source: none

Conflicts of interest: none

Received for publication: 19/08/2013

Accepted for publication: 17/12/2013

DESCRITORES - Hérnia ventral.

Questionário. Qualidade de vida. Laparoscopia. Parede abdominal.
RESUMO - Racional: A técnica de reparo de hérnia ventral via laparoscópica possibilitou operações com menor incisão na pele e menor dissecção dos tecidos moles ao redor da hérnia, portanto, melhor ferida operatória, rápido pós-operatório do paciente, retorno breve às atividades e menor taxa de complicações. Objetivo: Avaliar a aplicabilidade de um questionário de qualidade de vida baseado nos moldes da American Hernia Society, European Hernia Society e Carolinas Equation for Quality of Life em pacientes submetidos à hernioplastias laparoscópicas da parede abdominal anterior (incisional/ epigástrica/ umbilical). Método: Em estudo retrospectivo de coorte envolvendo total de 21 pacientes no pós-operatório de 12 meses de hernioplastia laparoscópica da parede abdominal anterior pela técnica de "intraperitoneal onlay mesh" foram submetidos, por via telefônica, ao questionário da qualidade de vida. Resultados - Dos 21 pacientes, 19\% sentiram retorno da hérnia e $81 \%$ relataram que nada aconteceu. Além disso $19 \%$ passaram por outra operação abdominal, sendo que dentre esses, 75\% estava relacionada à hérnia previamente corrigida e $81 \%$ não passaram por nenhuma outra operação abdominal. Conclusão - Foi possível aplicar o questionário de qualidade de vida por via telefônica; a qualidade referida foi satisfatória e mostrou que os pacientes, de modo geral, ficaram satisfeitos com o procedimento cirúrgico.

\section{INTRODUCTION}

$\mathrm{T}$ he anterior abdominal wall hernias (epigastric, ventral, umbilical, incisional) may be congenital or acquired. The epigastric occurs mainly correlated with diastasis of rectus abdominis muscles. The incisional hernia is a complication of laparotomy (3-13\%) and less occasional in laparoscopy $(0.8-2.8 \%)^{5,10,11}$.

Initially, hernia correction (herniorraphies) was performed by simple 
suture through open surgery, presenting recurrence rates of about $10-50 \%{ }^{11}$. Now with the introduction of prostheses (mesh) in hernia repair (hernioplasty) by open surgery, recurrence decreased $3-18 \% 1,5$.

In the 90 s, when LeBlanc and Booth described the mesh bridged laparoscopic hernioplasty technique, in which hernia recurrence remained around $10 \%$, similar to the open mesh hernioplasty ${ }^{1,8}$. It seems that laparoscopic technique has several advantages over traditional open surgery technique, such as shorter hospital stay, with a two day average ${ }^{6,14}$, and reduction in wound complications, such as infections, due to less soft tissue dissection around the hernia ${ }^{5}$. Moreover, a laparoscopic approach allows smaller incisions, being three in average, where two are 5 $\mathrm{mm}$ and one $10 \mathrm{~mm}^{11}$, providing a more acceptable esthetics than open surgery, where incision depends on hernia size.

In anterior abdominal wall laparoscopic hernioplasty, the mesh is anchored by sutures or staples, with at least $5 \mathrm{~cm}$ margins, on the hernial defect inside the peritoneum and in contact with the abdominal viscera ${ }^{3,15}$. This technique is called intraperitoneal onlay mesh or IPOM.

This study had the intention to evaluate the applicability of a quality of life survey through telephone in patients submitted to laparoscopic hernioplasty.

\section{METHODS}

Between November $11^{\text {th }} 2005$ and May 21 $1^{\text {st }}$ 2012, 62 patients underwent anterior abdominal wall laparoscopic hernioplasty (incisional, umbilical, epigastric) by IPOM technique by the same surgeon in São Paulo. The prostheses used were Composix (Bard), dualmesh (Gore), proceed (Johnson) and dynamesh IPOM.

In May 2013 contact of these patients through telephone was attempted for the application of a quality of life questionnaire based on the American Hernia Society, European Hernia Society and Carolinas Equation for Quality of Life ${ }^{2,9,12}$. Of these 62 patients, only 21 were able to respond the questionnaire, since 36 were not possible to reach and five refused to answer.

When contact was managed, the investigator explained what composed the questionnaire of quality of life after anterior abdominal wall hernioplasty. The collected data would be converted into statistics. In addition, the patient was informed that this study would maintain the privacy of their identity and with his/her consent the questionnaire could be applied.

The questionnaire consisted of 12 questions that evaluated the quality of life of individuals after one year of surgery (Figure 1).
1. Do you feel that your hernia is back? Yes/No

2. Have you ever had another abdominal surgery? Yes (hernia related or not)/No

3. My abdominal wall has a major impact on my health. Strongly disagree/Moderately disagree/Slightly disagree/Slightly agree/Moderately agree/Strongly agree

4. My abdominal wall causes me pain. Strongly disagree/ Moderately disagree/Slightly disagree/Slightly agree/ Moderately agree/Strongly agree

5. My abdominal wall interferes when I practice heavy physical exercise. Ex: lifting weights. Strongly disagree/Moderately disagree/Slightly disagree/Slightly agree/Moderately agree/ Strongly agree

6. My abdominal wall interferes when I practice moderate physical activities. Ex: bowling, abdominals. Strongly disagree/Moderately disagree/Slightly disagree/Slightly agree/Moderately agree/Strongly agree

7. My abdominal wall interferes when I walk or climb stairs. Strongly disagree/Moderately disagree/Slightly disagree/ Slightly agree/Moderately agree/Strongly agree

8. I often stay at home because of my abdominal wall. Strongly disagree/Moderately disagree/Slightly disagree/Slightly agree/Moderately agree/Strongly agree

9. I perform less housework because of my abdominal wall. Strongly disagree/Moderately disagree/Slightly disagree/ Slightly agree/Moderately agree/Strongly agree

10. I perform less work tasks because of my abdominal wall. Strongly disagree/Moderately disagree/Slightly disagree/ Slightly agree/Moderately agree/Strongly agree

11. My abdominal wall interferes in the way I feel every day. Strongly disagree/Moderately disagree/Slightly disagree/ Slightly agree/Moderately agree/Strongly agree

12. I often feel sad because of my abdominal wall. Strongly disagree/Moderately disagree/Slightly disagree/Slightly agree/Moderately agree/Strongly agree

FIGURE 1 - Questionnaire used by telephone interview with the operated patients (based on the American Hernia Society and European Hernia Society Carolinas Equation for Quality of Life)

RESULT

It took an average of 10 minutes to complete the questionnaire by telephone.

Of the 21 patients, $19 \%$ felt that the hernia recurred and $81 \%$ reported that nothing happened since surgery. Also $19 \%$ passed through another abdominal wall surgery, and among these, 75\% was related to the previously hernia correction. Finally, $81 \%$ of patients did not undergo any other abdominal wall surgery, as presented in Table 1. 
TABLE 1 - Questions concerning hernia relapse (1 and 2)

\begin{tabular}{|c|c|c|c|c|}
\hline & \multicolumn{2}{|c|}{ YES } & NO & TOTAL \\
\hline $\begin{array}{l}\text { 1. Do you feel } \\
\text { that your hernia is } \\
\text { back? }\end{array}$ & \multicolumn{2}{|c|}{4} & 17 & 21 \\
\hline $\begin{array}{l}\text { 2. Have you ever } \\
\text { had another } \\
\text { abdominal } \\
\text { surgery? }\end{array}$ & $\begin{array}{c}3 \\
\text { (hernia related) }\end{array}$ & $\begin{array}{l}1 \\
\text { (not hernia } \\
\text { related) }\end{array}$ & 17 & 21 \\
\hline
\end{tabular}

Table 2 demonstrates numerically the answers of the interviewed for questions 3 through 12 .

\section{DISCUSSION}

When choosing a questionnaire to assess quality of life through telephone, three factors must be considered: 1 ) the questionnaire size cannot be either to short or too long, since the first may not provide sufficient information and the second can fatigue or decrease patient compliance; 2) there must be a range of questions, from physical to psychological changes; 3 ) has to be easily comprehended, having concise and objective questions.

Questionnaire administration through telephone has its facilities and difficulties. Even if these means are cheap and with easy management of results than the face to face questionnaire application ${ }^{4}$, difficulties do stand out, such as lower collaboration rates, according to some studies ${ }^{7,13}$.

When using a telephone device, the interviewer can perform the questionnaire in any environment, without the need to schedule a personal meeting with the patient. However, the lack of personal contact can discourage the patient to value the importance of the study, responding with indifference or refusal. Another difficulty, seen in this analysis, was the fact that contact was made in business hours (Wednesdays from 4 to 8 PM). In this case most patients could not answer and did not return calls.

The questionnaire used in this study, based on the American Hernia Society, European Hernia Society and Carolinas Equation for Quality of Life, was very well accepted by patients who have participated, since only one, out of 26 patients, did not complete the whole questionnaire.

The investigator's perception in relation to the questionnaire was of easy appliance and comprehension. Patients had comprehension doubts in relation to one question (number 3 ), with no compromise in research results. Patients had difficulty in understanding the concept of the importance of the abdominal wall in their lives and could be evaluated in future studies.

\section{CONCLUSION}

It was possible to apply the quality of life questionnaire by telephone in patients who underwent laparoscopic ventral hernia. The results, in turn, were satisfactory and showed that patients, in general, were satisfied with the surgical procedure.

TABLE 2 - Answers to the questions of numbers 3-12

\begin{tabular}{|c|c|c|c|c|c|c|c|}
\hline & $\begin{array}{l}\text { STRONGLY } \\
\text { DISAGREE }\end{array}$ & $\begin{array}{l}\text { MODERATELY } \\
\text { DISAGREE }\end{array}$ & $\begin{array}{l}\text { SLIGHTY } \\
\text { DISAGREE }\end{array}$ & $\begin{array}{l}\text { SLTHGY } \\
\text { AGREE }\end{array}$ & $\begin{array}{l}\text { MODERATELY } \\
\text { AGREE }\end{array}$ & $\begin{array}{l}\text { STRONGLY } \\
\text { AGREE }\end{array}$ & TOTAL \\
\hline $\begin{array}{l}\text { My abdominal wall has a major impact on } \\
\text { my health }\end{array}$ & $\begin{array}{c}3 \\
(14,2 \%)\end{array}$ & $\begin{array}{c}1 \\
(4,7 \%)\end{array}$ & 0 & $2(9,5 \%)$ & $5(23,8 \%)$ & $10(47,6 \%)$ & 21 \\
\hline My abdominal wall causes me pain & $\begin{array}{c}15 \\
(71,4 \%)\end{array}$ & $\begin{array}{c}1 \\
(4,7 \%)\end{array}$ & 0 & 0 & $4(19,0 \%)$ & $\begin{array}{c}1 \\
(4,7 \%)\end{array}$ & 21 \\
\hline $\begin{array}{l}\text { My abdominal wall interferes when I practice } \\
\text { heavy physical exercise Ex: lifting weight }\end{array}$ & $\begin{array}{c}9 \\
(42,8 \%)\end{array}$ & $3(14,2 \%)$ & $2(9,5 \%)$ & $2(9,5 \%)$ & $\begin{array}{c}1 \\
(4,7 \%)\end{array}$ & $4(19,0 \%)$ & 21 \\
\hline $\begin{array}{l}\text { My abdominal wall interferes when I practice } \\
\text { moderate physical activities Ex: bowling, } \\
\text { abdominals }\end{array}$ & $\begin{array}{c}14 \\
(66,6 \%)\end{array}$ & $3(14,2 \%)$ & 0 & 0 & $3(14,2 \%)$ & $\begin{array}{c}1 \\
(4,7 \%)\end{array}$ & 21 \\
\hline $\begin{array}{l}\text { My abdominal wall interferes when I walk or } \\
\text { climb stairs }\end{array}$ & $\begin{array}{c}18 \\
(85,7 \%)\end{array}$ & 0 & $1(4,7 \%)$ & 0 & $\begin{array}{c}2 \\
(9,5 \%)\end{array}$ & 0 & 21 \\
\hline $\begin{array}{l}\text { I often stay at home because of my } \\
\text { abdominal wall }\end{array}$ & $\begin{array}{c}15 \\
(71,4 \%)\end{array}$ & $3(14,2 \%)$ & 0 & $2(9,5 \%)$ & $\begin{array}{c}1 \\
(4,7 \%)\end{array}$ & 0 & 21 \\
\hline $\begin{array}{l}\text { I perform less housework because of my } \\
\text { abdominal wall }\end{array}$ & $\begin{array}{c}16 \\
(76,1 \%)\end{array}$ & $\begin{array}{c}2 \\
(9,5 \%)\end{array}$ & 0 & 0 & $\begin{array}{c}2 \\
(9,5 \%)\end{array}$ & $\begin{array}{c}1 \\
(4,7 \%)\end{array}$ & 21 \\
\hline $\begin{array}{l}\text { I perform less work tasks because of my } \\
\text { abdominal wall }\end{array}$ & $\begin{array}{c}14 \\
(66,6 \%)\end{array}$ & $3(14,2 \%)$ & 0 & $1(4,7 \%)$ & $\begin{array}{c}2 \\
(9,5 \%)\end{array}$ & $\begin{array}{c}1 \\
(4,7 \%)\end{array}$ & 21 \\
\hline $\begin{array}{l}\text { My abdominal wall interferes in the way I feel } \\
\text { every day }\end{array}$ & $\begin{array}{c}14 \\
(66,6 \%)\end{array}$ & $4(19,0 \%)$ & $1(4,7 \%)$ & 0 & $\begin{array}{c}2 \\
(9,5 \%)\end{array}$ & 0 & 21 \\
\hline I often feel sad because of my abdominal wall & $\begin{array}{c}18 \\
(85,7 \%)\end{array}$ & $\begin{array}{c}2 \\
(9,5 \%)\end{array}$ & 0 & 0 & $\begin{array}{c}1 \\
(4,7 \%)\end{array}$ & 0 & 21 \\
\hline
\end{tabular}




\section{REFERENCES}

1. Abdalla RZ, Garcia RB, Costa RID, Luca CRP, Abdalla BMZ. Procedimento de Rives/Stoppa modificado robô-assistido para correção de hérnias ventrais da linha média. $A B C D$, arq. bras. cir. dig. 2012; 25:129-132.

2. AHSQC Data Definitions (2013). Tab F: Patient Reported Outcomes. Available at https://ahsqc.org/Registry/static/ahs/content/ AHSQCDataDictionary.pdf?menuId=8036. Acessed 25 Jan 2014.

3. Berger D. Laparoscopic IPOM technique. Chirug. 2010; 81:211-5.

4. Chwalow AJ; Costagliola D; Stern J; Mesbah M; Eschwege E. Telephone versus face to face interviewing as a means of collecting data relevant to the management of diabetes among general practitioners in France: a randomized design. Diabete Metab. 1989; 15:157-60

5. Claus CMP, Loureiro MP, Dimbarre D, Cury AM, Campos ACL, Coelho JCU. Laparoscopic incisional hernioplasty: experience of 45 cases. $A B C D$, arq. bras. cir. dig. 2011; 24:121-125

6. Eriksen JR, Poornoroozy P, Jørgensen LN, Jacobsen B, FriisAndersen $\mathrm{HU}$, Rosenberg J. Pain, quality of life and recovery after laparoscopic ventral hernia repair. Hernia. 2009; 13:13-21

7. García M; Rohlfs I; Vila J; Sala J; Pena A; Masiá R; Marrugat J. Comparison between telephone and self-administration of Short Form Health Survey Questionnaire (SF-36). Gac Sanit. 2005; 19: 433-9.

8. Grant AM, EU Hernia Trialists Collaboration. Laparoscopic versus open groin hernia repair: meta-analysis of randomised trials based on individual patient data. Hernia. 2002; 6:2-10.
9. Heniford B (2012)The carolinas equation for quality of lifeCeQOL. carolinas health care system. Available at http:// www. carolinashealthc are. org/ cmc-surgery-ceqol-educationalmaterials. Accessed 11 Nov 2012.

10. Heniford BT, Park A, Ramshaw BJ, Voeller G. Laparoscopic ventral and incisional hernia repair in 407 patients. J Am Coll Surg. 2000; 190:645-50.

11. Misiakos EP, Machairas A, Patapis P, Liakakos T. Laparoscopic ventral hernia repair: pros and cons compared with open hernia repair. JSLS. 2008; 12:117-25.

12. Simons MP, Aufenacker T, Bay-Nielsen M, Bouillot JL, Campanelli G, Conze J, Lange D, Fortelny R, Heikkinen $T$, Kingsnorth $A$, Kukleta J, Morales-Conde S, Nordin P, Schumpelick V, Smedberg S, Smietanski M, Weber G, Miserez M. European Hernia Society guidelines on the treatment of inguinal hernia in adult patients. Hernia 2009; 13:343-403.

13. Weinberger M, Oddone EZ, Samsa GP, Landsman P. Are healthrelated quality-of-life measures affected by the mode of administration? J Clin Epidemiol. 1996; 49:135-40.

14. Yavuz N, Ipek T, As A, Kapan M, Eyuboglu E, Erguney S. Laparoscopic repair of ventral and incisional hernias: our experience in 150 patients. J Laparoendosc Adv Surg Tech A. 2005; 15:601-5.

15.Zinther NB, Wara P, Friis-Andresen $\mathrm{H}$. Intraperitoneal onlay mesh: an experimental study of adhesion formation in a sheep model. Hernia. 2010; 14:283-9. 